\title{
Simposio \\ Clima y modelos ecológicos DE ENFERMEDADES PARASITARIAS
}

\section{Modelos climáticos para Fasciola hepatica en Colombia}

\author{
Natalia Valencia-López¹, John B. Malone², Luz Velásquez¹, Catalina Gómez \\ 1 Línea de Investigación Malacología médica y trematodos, Programa de Estudio y Control de \\ Enfermedades Tropicales, Facultad de Medicina, Universidad de Antioquia, Medellín, Colombia \\ 2 College of Veterinary Medicine, Pathobiological Sciences, Louisiana State University, Baton Rouge, \\ LA, USA
}

La ocurrencia de fasciolosis bovina está altamente relacionada con algunas condiciones ambientales (Olaechea, 1994; Dutra, et al., 2010), hecho que permite asociar información de prevalencia con datos climáticos, como una manera válida de explorar la variabilidad espacial y temporal de esta parasitosis (Malone, 1997; Fuentes, et al., 1999; Malone y Yilma, 1999; Fuentes, 2006). En este sentido, los sistemas de información geográfica brindan una herramienta eficaz que ayuda a relacionar los datos de prevalencia con las condiciones ambientales.

El propósito de este estudio es contribuir al conocimiento epidemiológico de esta parasitosis, usando información de prevalencia y algunos datos ambientales para predecir su distribución espacial y temporal.

\section{Métodos}

Se construyó un sistema de información geográfica para Colombia ejecutando una zona de transición (buffer) de $1 \mathrm{~km}$ y utilizando datos de prevalencia, con el fin de identificar valores críticos del índice de vegetación mejorado (Moderateresolution Imaging Spectroradiometer, MODIS), altitud (Shuttle Radar Topographic Mission, SRTM) y temperatura de la superficie de la tierra en el día y en la noche (de MODIS). Los datos de prevalencia se obtuvieron mediante un estudio realizado entre el 2008 y el 2010, en tres subregiones del departamento de Antioquia, al noroeste de Colombia.

La humedad y la temperatura, como factores que influyen directamente en los niveles de prevalencia y la transmisión de fasciolosis (Olaechea, 1994) fueron evaluados para Colombia, calculando un índice de pronóstico basado en el clima. Este índice se basa en los conceptos de grado día de crecimiento y balance de agua, y fue calculado siguiendo lo propuesto por Yilma y Malone (1998):
Index $=G D D \times$ days in month, if $[P R E-(P E T \times 0.8)>0]$ , ecuación 1.

Con el propósito de evaluar el riesgo temporal de fasciolosis en Antioquia, se calculó un segundo índice. Este índice (ecuación 2) se basa en un sistema desarrollado por Malone, et al. (1987) y que luego fue adaptado por Malone, et al. (1998), para uso a nivel regional; se calculó usando datos de temperatura máxima y mínima e información de precipitación de una estación meteorológica ${ }^{1}$ ubicada en el norte antioqueño, y un software desarrollado por Malone, et al. (1987):

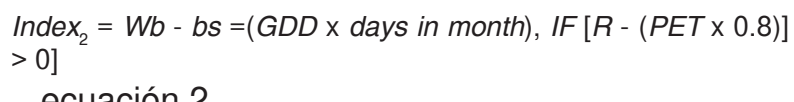
ecuación 2.

\section{Resultados}

Sistema de información geográfica

Las prevalencias en los municipios muestreados variaron entre $0,3 \%$ y $51,3 \%$, con una media de $21,56 \%(D E=16,80)$.

Las extracciones realizadas nos permitieron identificar valores dríticos de las variables ambientales consideradas, las cuales son relevantes para el asentamiento del sistema caracolparásito (tabla 1).

El área adecuada para la presencia de fasciolosis en Antioquia, para todos los situaciones analizadas, representa entre el $28 \%$ y el $31,33 \%$ del área adecuada para todo el país y corresponde, principalmente, a la región andina.

\section{Índices de pronóstico}

Los valores anuales del índice 1 variaron entre 0 y 7.117, como algunas de las áreas con los

\footnotetext{
'Esta estación meteorológica y los datos usados en este estudio son propiedad de Empresas Públicas de Medellín (EPM). Está ubicada en $6^{\circ} 39^{\prime}$ norte y $75^{\circ} 30^{\prime}$ oeste, código IDEAM número 2701523.
} 
Tabla 1. Valores críticos de las variables ambientales consideradas.

\begin{tabular}{lcc}
\hline Variable & $\mathbf{2 0 0 8}$ & Rango \\
\hline Índice de vegetación mejorada & $\mathbf{2 0 0 9}$ \\
Altitud (msnm) & $0.38-0.61$ & $0.36-0.57$ \\
Temperatura de la superficie de la tierra en el día $\left({ }^{\circ} \mathrm{C}\right)$ & $2097.25-2629.43$ & $2160.13-2789.26$ \\
Temperatura de la superficie de la tierra en la noche $\left({ }^{\circ} \mathrm{C}\right)$ & $17.16-20.58$ & $15.40-20.11$ \\
\hline
\end{tabular}

*El valor del índice varía entre 0 , lo que indica que no hay vegetación, hasta 1 , que indica que hay vegetación densa.

índices más altos están ubicadas en regiones con temperaturas promedio por encima de los $25^{\circ} \mathrm{C}$, lo cual es una condición que restringe el desarrollo del sistema caracol-parásito, fue necesario usar una máscara para excluir estos lugares; como resultado, se obtuvo un mapa de riesgo más preciso que coincidió en señalar la zona andina como la de mayor riesgo para la presencia de la parasitosis.

Según Fuentes y Malone (1999) y Fuentes, et al. (1999), los valores mensuales de Wb-bs por debajo de 600 indican que no hay riesgo, entre 601 y 1.500 indican bajo riesgo, entre 1.501 y 3.000 representan riesgo moderado y por encima de 3.000 indican alto riesgo. Basados en la evolución anual del índice $\mathrm{Wb}$-bs, el período óptimo para la transmisión de fasciolosis en el norte de Antioquia varía entre los dos períodos analizados (año La Niña, 2007 a 2008, y año El Niño 2008 a 2009). Para marzo de 2007 a febrero de 2008, hubo dos períodos óptimos, uno prolongado que iba desde junio hasta agosto, y uno corto, desde diciembre hasta febrero. Por otro lado, para marzo de 2008 a febrero de 2009 , sólo hubo un período óptimo, el cual iba de agosto a septiembre.

\section{References}

1. Dutra LH, Molento MB, Naumann CRC, Biondo AW, Fortes FS, Savio D, Malone JB, Mapping risk of bovine fasciolosis in the south of Brazil using Geographic Information Systems. Vet Parasitol. 2010;169:76-81.

2. Fuentes MV, Malone JB. Development of a forecast system for fasciolosis in central Chile using remote sensing and climatic data in a geographic information system. Research and Reviews in Parasitology. 1999;59:129-134.

3. Fuentes MV, Valero MA, Bargues MD, Esteban JG. Analysis of climatic data and forecast indices for human fascioliasis at very high altitude. Ann Trop Med Parasitol. 1999;93:835-50.

4. Fuentes MV. Remote sensing and climate data as a key for understanding fasciolosis transmission in the Andes: review and update of an ongoing interdisciplinary project. Geospat Health. 2006;1:5970.

5. Malone JB, Williams TE, Muller RA, Geaghan JP, Loyacano AF.. Fasciolosis in cattle in Louisiana: development of a system to predict disease risk climate, using the Thornthwaite water budget. Am J Vet Res. 1987;48:1167-170.

6. Malone JB, Zukowski SH, Geographic models and control of cattle liver flukes in the southern USA. Parasitol Today. 1992;8:266-70.

7. Malone JB, The landscape epidemiology of fasciolosis: geographic determinants of disease risk. In: Boray JC, editor. Inmunology, pathobiology and control of fasciolosis. New Jersey; 1997. p. 61-85.

8. Malone JB, Yilma JM, Predicting outbreaks of fasciolosis: from ollerenshaw to satellites. In: Dalton JP, editor. Fasciolosis. Dublin: School of Biotechnology; 1999. p. 151-182.

9. Olaechea FV. Epidemiología y control de Fasciola hepatica en la Argentina. En: Nari A, Fiel C, editores. Enfermedades parasitarias de importancia económica en bovinos. Buenos Aires: Ed. Hemisferio Sur; 1994. p. 213-33.

10. Yilma JM, Malone JB. A geographic information system forecast model for strategic control of fasciolosis in Ethiopia. Vet Parasitol. 1998;78:103-27. 


\title{
Modeling neglected tropical diseases in Colombia and Bolivia
}

\author{
P. Nieto ${ }^{1}$, J. B. Malone ${ }^{1}$, P. Vounatsou' ${ }^{2}$, J. C. McCarroll ${ }^{1}$ \\ ${ }^{1}$ Louisiana State University, Baton Rouge, LA, USA \\ 2 Swiss Tropical and Public Health Institute, Basel, Switzerland
}

In Latin America and the Caribbean neglected tropical diseases are the most common infections of approximately 200 million of the poorest people in the region (Hotez, et al., 2008). Neglected tropical diseases primarily occur in the poorest and the most marginalized communities where unsafe water, poor sanitation and limited access to basic health care are rife. Control efforts require reliable baseline maps of the geographical distribution of the disease burden and population at risk to allow better targeting of planned interventions at the high risk areas.

This work integrates compiled disease from ministries of health, research institutions and publications with environmental, climatic and socio-economical factors to create statistical models to identify the most significant predictors of disease transmission and provide a mathematical description of the disease-predictors that can be used for control purposes.

The maximum entropy (MaxEnt) was used for generating probability surfaces of the geographical distributions of neglected tropical diseases. The final results were models that predict areas where the diseases are most likely to occur based on environmental correlations.

Ecological niche modeling using MaxEnt focused on vectors of Chagas disease and diseases data on Chagas and leishmaniasis in Colombia were used as prototypes to develop methodologies for model development for other neglected tropical diseases of interest in Bolivia and Brazil.

\section{Ecological niche models and the distribution and abundance of hookworms in Bolivia}

\author{
J. B. Malone ${ }^{1}$, P. Nieto', P. Vounatsou², J. C. McCarroll \\ ${ }^{1}$ Louisiana State University, Baton Rouge, LA, USA \\ ${ }^{2}$ Swiss Tropical and Public Health Institute, Basel, Switzerland
}

The predictive value of maximum entropy (MaxEnt) geostatistical models (1) and empirical models based on the growing degree day-water budget (GDD/WB) concept $(2,3)$ were compared as methods of mapping the distribution and abundance of hookworm in Bolivia.

MaxEnt is a general purpose ecological niche modeling software that can be used to predict species geographic distribution when only occurrence data are available for analysis (e. g., vector occurrence, case incidence). GDD/WB models are based on known thermal-hydrological preferences and limits of tolerance of a biological system in the environment.

A climate grid of Bolivia $\left(18 \mathrm{~km}^{2}\right.$, monthly long term normal temperature, rainfall, evapotranspiration) was used to calculate the annual number of transmission cycles of free-living stages $\left(\right.$ egg- $\left.\mathrm{L}_{3}\right)$ of Necator americanus possible in each grid cell using a base temperature of $15^{\circ} \mathrm{C}$ (below which no development progresses) conditional on a water budget threshold of $>0,5$ soil moisture, and reported mean $\mathrm{L}_{3}$ longevity to derive a cumulative value of 260 GDD per transmission cycle (annual GDD if $>0.5 / 260$ ).

A risk map based on potential transmission cycles per year revealed an elevation gradient of suitability in Bolivia that ranged from no transmission at high elevation altiplano sites and in arid zones to 13 potential transmission cycles at hot, humid Amazonian sites. Model output was significantly related to 35 municipality level survey prevalence data records, range $0-80 \%$.

MaxEnt geostatistical model analysis yielded a probability surface map that ranged from a 0.0024 to 0.815 probability of occurrence. MaxEnt threshold analysis was performed by running separate models based on survey points of $<2 \%$ prevalence and $>2 \%$ prevalence, revealing a low risk altiplano zone and a variable predicted probability gradient from the eastern slopes of the Andes to Amazon ecological zones.

The potential value and limitations of the two modeling approaches will be discussed. 


\section{References}

1. Phillips SJ, Anderson RP, Schapire RE. Maximum entropy modeling of species geographic distributions. Ecol Modell. 2006;190:231-59.

2. Malone JB. Biology-based mapping of vector-borne parasites by geographic information systems and remote sensing. Parassitologia. 2005;47:27-50.

3. Nieto P, Malone JB, Bavia ME. Ecological niche modeling for visceral leishmaniasis in the state of Bahia, Brazil, using genetic algorithm for rule-set prediction and growing degree day-water budget analysis. Geospat Health. 2006;1:115-26.

\section{Fasciolosis in Perú}

Laura Rinaldi ${ }^{1}$, Sergio González²${ }^{2}$, Jorge Guerrero ${ }^{3}$, Vincenzo Musella ${ }^{4}$, Giuseppe Cringoli ${ }^{1}$

1 Department of Pathology and Animal Health, University of Naples Federico II, Naples, Italy

2 Fondo de Crédito para el Desarrollo Agroforestal, Cajamarca, Perú

3 Department of Pathobiology, School of Veterinary Medicine, University of Pennsylvania, Philadelphia, PA, USA

${ }^{4}$ Department of Clinical and Experimental Medicine, University of Catanzaro Magna Graecia, Catanzaro, Italy

The liver infection fasciolosis is caused by the liver flukes Fasciola hepatica and Fasciola gigantica. These trematodes parasitize humans and a broad range of domestic animals (e.g., sheep and cattle) and wild animals (e.g., rabbits, beavers, deer and rats) (1) . Fascioliosis exhibits an exceptionally large latitudinal, longitudinal and altitudinal distribution. Indeed, human infections have been reported from five continents in 51 countries (2). Recent estimates suggest that more than 90 million people are at risk of fascioliosis and between 2.4 and 17 million individuals are infected (3). However, not all countries have established reporting systems and recent outbreaks were not considered in these estimates, and hence the "true" number of Fasciola infections might be considerably higher (2). Also, the worldwide incidence of fascioliosis in sheep and cattle is more than 250 and 300 million, respectively, causing an estimated economic loss of US\$ 3 billion to agriculture each year through losses of milk and meet yields $(1,4)$. For these reasons, there is a need for accurate and sensitive epidemiological and diagnostic tools, so that the true extend and global burden of fascioliosis can be estimated and the impact of interventions quantified and monitored (3).

Fasciolosis, as any health problem, is an outcome of multiple determinants and geospatial tools can answer questions about the complex web of causation of epidemiological patterns of infections. Furthermore the importance of using these tools is due to the fact that the challenge for gaining largescale control programs for parasitic infections of human and animals, including fasciolosis, in developing and developed countries cannot be addressed without considering both abiotic and biotic environmental factors that affect the maintenance and transmission of the parasites.

For these reasons, the application of geospatial tools, as Geographical Information Systems (GIS), Global Positioning System (GPS), Satellite based Remote Sensing (RS) and Virtual Globes (e.g., Google Earth ${ }^{\mathrm{TM}}$ ) to spatial epidemiology in human and animal health have been firmly established for mapping, forecasting, monitoring, early warning and surveillance $(5,6,7)$.

Fasciola hepatica is a good candidate for geospatial tools owing to its environmental sensitivity, tendency to year-to-year geographic stability in snail host habitat distribution, relative longevity in mammalian hosts, confinement of livestock in identifiable grazing areas. Critical factors for $F$. hepatica development are temperature and humidity and the Normalized Difference Vegetation Index (NDVI) obtained from RS is associated with suitable moisture availability to external stages of liver fluke (8).

The countries located on the slopes of the Andes, i.e., Perú, Bolivia and Chile are the most severely affected by $F$. hepatica infections for both humans and animals (2). Due to the importance of fasciolosis in the Cajamarca valley of Perú (9), a project titled "Control integrado de la distomatosis hepática en la Región Cajamarca, Cajabamba, San Marcos, Celendín, San Pablo, San Miguel" promoted by Foncreagro (Fondo de Crédito para el Desarrollo Agroforestal) has recently started.

The study area (78'48'31'N - 6०40'20"S; $\left.77^{\circ} 56^{\prime} 49^{\prime \prime} \mathrm{N}-7^{\circ} 45^{\prime} 35^{\prime \prime} \mathrm{S}\right)$ includes 6 provinces, 17 districts and circa 700 hamlets (caseríos). Geospatial tools (for territorial sampling, mapping, climate-based forecasting and surveillance) 
together with new sensitive diagnostic techniques, the FLOTAC techniques (10), will be used in the project within an integrated approach for control of fasciolosis in animals and humans.

\section{References}

1. Robinson M, Dalton JP. Zoonotic helminth infections with particular emphasis on fasciolosis and other trematodiases. Philos Trans R Soc Lond B Biol Sci. 2009;364:2763-76.

2. Mas-Coma S, Valero MA, Bargues MD. Fasciola, lymnaeids and human fascioliasis, with a global overview on disease transmission, epidemiology, evolutionary genetics, molecular epidemiology and control. Adv Parasitol. 2009;69:41-146.

3. Keiser J, Utzinger J. Food-borne trematodiases. Clin Microbiol Rev. 2009;22:466-83.

4. Mas-Coma S, Bargues MD, Valero MA. Fascioliasis and other plant-borne trematode zoonoses. Int $\mathrm{J}$ Parasitol. 2005;35:1255-78.

5. Cringoli G, Rinaldi L, Veneziano V, Musella V. Disease mapping and risk assessment in veterinary parasitology: some case studies. Parassitologia. 2005;47: 9-25.

6. Rinaldi L, Musella V, Biggeri A, Cringoli G. New insights into the application of geographical information systems and remote sensing in veterinary parasitology. Geospat Health. 2006;1:33-47.

7. Bergquist R, Rinaldi L. Health research based on geospatial tools: a timely approach in a changing environment. J Helminthol. 2010;84:1-11.

8. Malone JB, Nieto P, Tadesse A. Biology-based mapping of vector-borne parasites by geographic information systems and remote sensing. Parassitologia. 2006;48:77-9.

9. Claxton JR, Zambrano H, Ortiz P, Delgado E, Escurra E, Clarkson MJ,. Strategic control of fasciolosis in the inter-Andean valley of Cajamarca, Perú. Vet Rec. 1998;11:42-5.

10. Cringoli G, Rinaldi L, Maurelli MP, Utzinger J. FLOTAC: new multivalent techniques for qualitative and quantitative copromicroscopic diagnosis of parasites in animals and humans. Nat Protoc. 2010;5:503-15. 